\title{
Pb-PHYTOEXTRACTION BY MAIZE IN A Pb-EDTA TREATED OXISOL
}

\author{
Bruno Fernando Faria Pereira ${ }^{1}$; Cleide Aparecida de Abreu ${ }^{2 *}$; Solange Romeiro ${ }^{2}$; Ana Maria \\ Magalhães Andrade Lagôa ${ }^{2}$; Antônio Paz-González ${ }^{3}$ \\ ${ }^{1}$ USP/ESALQ - Programa de Pós-Graduação em Solos e Nutrição de Plantas. \\ IAC - Centro de Pesquisa e Desenvolvimento de Solos e Recursos Ambientais, Av. Barão de Itapura, CP 28 - \\ 13020-902 - Campinas, SP - Brasil. \\ ${ }^{3}$ Universidad La Coruña, Facultad de Ciências, A Zapateira, 15071 - La Coruña - Spain. \\ *Corresponding author <cleide@iac.sp.gov.br>
}

\begin{abstract}
One of the most viable strategies to restore metal contaminated soils is the introduction of plants specialized in their accumulation or able to tolerate very high metal concentrations. This research evaluated: i. the maize as a $\mathrm{Pb}$-accumulator plant; ii. the effects of EDTA-chelating agent for $\mathrm{Pb}$-uptake by maize; iii. amending effect of EDTA on the soil Pb-availability using different extracts. Treatments consisted of $\mathrm{Pb}$ rates $\left(100 ; 200 ; 350 ; 1,200\right.$ and 2,400 $\mathrm{mg} \mathrm{kg}^{-1}$ ) applied to a Rhodic Hapludox in the form of $\mathrm{Pb}_{3}(\mathrm{NO})_{2}$ with $\left(0.5 \mathrm{~g} \mathrm{~kg}^{-1}\right)$ and without EDTA. Lead concentrations were determined in maize plant shoots. Soil available Pb was obtained using DTPA, Mehlich-3 and saturation solutions methods. Ionic speciation in the soil solution was performed using the software Visual-Minteq. Although a low $t$ value was found $(t<0.70)$, $\mathrm{Pb}$ concentration were high $\left(>1,500 \mathrm{mg} \mathrm{kg}^{-1}\right.$ of $\left.\mathrm{Pb}\right)$ in maize shoots regardless of EDTA addition. Maize plants treated with EDTA had lower dry matter yield, mainly due to toxic levels of $\mathrm{Fe}$ and $\mathrm{Al}$ of the Oxisol. All extracting solutions were effective to determine available $\mathrm{Pb}$ in soil samples, but the saturation extract is a more difficult and time consuming procedure. At low and medium $\mathrm{Pb}$ levels, the plants grew less on EDTA, therefore the phytoextration process was less efficient. The addition of EDTA to the soil is not recommended with the purpose of increasing $\mathrm{Pb}$ absorption by maize plants.
\end{abstract}

Key words: Mehlich-3, DTPA, phytoremediation, available $\mathrm{Pb}$, ionic speciation

\section{FITOEXTRAÇÃO DE Pb POR MILHO EM UM LATOSSOLO TRATADO COMPb EEDTA}

\begin{abstract}
RESUMO: Uma das estratégias mais viáveis para a descontaminação de solos é a introdução de plantas especializadas na acumulação ou que toleram altas concentrações de metais. Nesse estudo avaliaram-se: i. o potencial acumulador de $\mathrm{Pb}$ de plantas de milho; ii. os efeitos do EDTA na absorção de $\mathrm{Pb}$ pelo milho; iii. o efeito do EDTA na disponibilidade de $\mathrm{Pb}$ utilizando diferentes extratores. Os tratamentos consistiram em doses de $\mathrm{Pb}\left(100 ; 200 ; 350 ; 1.200\right.$ and $\left.2.400 \mathrm{mg} \mathrm{kg}^{-1}\right)$ aplicados em um Latossolo na forma de $\mathrm{Pb}_{3}(\mathrm{NO})_{2}$ com $\left(0.5 \mathrm{~g} \mathrm{~kg}^{-1}\right)$ e sem EDTA. A concentração de $\mathrm{Pb}$ foi determinada na parte aérea das plantas de milho, e no solo determinou-se o Pb disponível pelos métodos DTPA, Mehlich-3 e pasta de saturação. A especiação iônica da solução do solo foi determinada utilizando-se o software Visual-Minteq. Embora tenha sido encontrado um baixo valor $t(t<0.70)$, a concentração de $\mathrm{Pb}$ na parte aérea do milho foi alta $\left(>1.500 \mathrm{mg} \mathrm{kg}^{-1}\right)$, independente da adição de EDTA. As plantas de milho que receberam EDTA apresentaram redução na massa seca, principalmente devido aos níveis tóxicos de $\mathrm{Fe}$ e $\mathrm{Al}$ do Latossolo. Todas as soluções extratoras utilizadas foram eficientes em determinar o $\mathrm{Pb}$ disponível nas amostras de solo, mas a pasta de saturação foi o processo mais trabalhoso. Em baixa e média concentração de $\mathrm{Pb}$ no solo as plantas cresceram menos com EDTA, portanto a fitoextração foi menos eficiente. Não é recomendada a adição de EDTA no solo buscando aumentar a absorção de $\mathrm{Pb}$ pelas plantas de milho.

Palavras-chave: Mehlich-3, DTPA, fitorremediação, Pb disponível, especiação iônica
\end{abstract}

\section{INTRODUCTION}

Lead is a metal found in several products and materials worldwide used on a daily basis, such pig- ments, munitions, medical and electrical equipments, batteries, and is one of the most persistent contaminants in the soil (Kumar et al., 1995). Only in the State of São Paulo, Brazil, 217 heavy metal (HM) contami- 
nated locations have been registered, including $\mathrm{Pb}$ contaminated sites (CETESB, 2006).

Phytoextraction is a technique that uses plants able to accumulate high quantities of HM in their tissues. Such low cost technology has a great potential for in situ remediation of large areas with low or medium level of contamination. It has the advantage of being publicly well accepted since it is a 'green technology' that uses sunlight as the main source of energy (Chaney et al., 2000; Robinson et al., 2003 and USEPA, 2004). One of the major difficulties about this technique is to maintain high available $\mathrm{Pb}$ concentrations in soil solution. To correct this problem, the use of chelating agents might help $\mathrm{Pb}$ desorption from the soil matrix by forming a soluble complex, therefore increasing plant absorption (Shen et al., 2002). Among these, the addition of EDTA is considered the most effective technique, specially for $\mathrm{Pb}$ phytoextraction (Tandy et al., 2004; Huang et al., 1997). Many previous studies have shown the increase of $\mathrm{Pb}$ uptake by shoots using EDTA for numerous crops: maize, pea, cabbage, bean, wheat, indian mustard and rye (Huang et al., 1997; Blaylock, 1997; Shen et al., 2002; Schmidt, 2003; Hovsepyan \& Greipsson, 2005).

The metal availability to the plants may be determined by using saline, acid and/or chelating extracting solutions, or quantifying the element in the soil solution (Abreu et al., 2002). In non-contaminated soils, the use of extracting solutions for the evaluation of $\mathrm{Pb}$ availability to the plants, as well as its determination in the soil solution has not been successful because of its low concentration in soil extracts, very close to the equipment detection limits, which results in analytical errors (Bataglia et al., 1983).

Few studies have been found to date in the literature involving $\mathrm{Pb}$ phytoextraction and availability in Oxisols. Therefore, this research aimed at evaluating: (a) the maize as a Pb-accumulator plant on an Oxisol, (b) the effects of EDTA-chelating agent on the Pb-up- take by maize plants and (c) the EDTA amendment effect on soil $\mathrm{Pb}$-availability using the procedures of DTPA, Mehlich-3 and saturation extracting solutions.

\section{MATERIAL AND METHODS}

The experiment was carried out in a greenhouse, at Campinas, State of São Paulo, Brazil (2253' $\left.\mathrm{S} ; 47^{\circ} 03^{\prime} \mathrm{W}\right)$, in $3 \mathrm{dm}^{3}$ plastic pots filled with soil samples of a Rhodic Hapludox, during 2004. Maize (Zea mays L., cv. IAC-8333) was used as test plant.

\section{Soil sampling and handling}

Oxisol soil samples were collected from the 0$20 \mathrm{~cm}$ soil layer, at Campinas, SP, Brazil, from which subsamples were used to analyze physical and chemical attributes (Table 1). Air-dried soil samples were sieved through a $2 \mathrm{~mm}$-mesh screen and amended for acidity with $\mathrm{Ca}(\mathrm{OH})_{2}$ and $\mathrm{MgCO}_{3} \mathrm{Mg}(\mathrm{OH})_{2} \mathrm{H}_{2} \mathrm{O}$, at the ratio 4:1 (Ca: $\mathrm{Mg})$, to elevate the $\mathrm{pH}$ to 5.5 . After liming, soil samples were incubated for 30 days with the soil moisture maintained close to field capacity with distilled water, to provide complete soil-lime reaction.

\section{Trial procedures and experimental design}

The experiment was carried out in a completely randomized design, arranged in a $(6 \times 2)$ factorial (six $\mathrm{Pb}$ rates, with and without EDTA) with three replications. The $\mathrm{Pb}$ rates consisted of $\mathrm{Pb}\left(\mathrm{NO}_{3}\right)_{2}$ in $\mathrm{mg} \mathrm{kg}^{-1}$ : 0 (control); 100; 200; 350; 1,200 and 2,400. These five rates are equivalent to levels of: (a) alert; (b) intervention in agricultural areas; (c) intervention in residential areas; (d) intervention in industrial areas; and (e) twice the level of intervention in industrial areas, respectively, according to values of reference informed by CETESB (2001). The treated soil samples remained incubated for 5 months and soil moisture was monitored and maintained close to field capacity.

After the incubation period, $\mathrm{NH}_{4} \mathrm{NO}_{3}$ was added to soil samples to compensate the $\mathrm{N}$ from $\mathrm{Pb}\left(\mathrm{NO}_{3}\right)_{2}$, taking the highest rate as reference. Thus,

Table 1- Chemical and physical attributes of a Rhodic Hapludox before treatments. ${ }^{\dagger}$

\begin{tabular}{|c|c|c|c|c|c|c|c|c|c|c|c|c|c|c|c|c|}
\hline \multicolumn{17}{|c|}{ Liming } \\
\hline $\mathrm{OM}$ & $\mathrm{P}$ & $\mathrm{pH}$ & C.E.C & $\mathrm{K}$ & $\mathrm{Ca}$ & $\mathrm{Mg}$ & $\begin{array}{c}\text { Base } \\
\text { Saturation }\end{array}$ & $\mathrm{B}$ & $\mathrm{Cu}$ & $\mathrm{Fe}$ & $\mathrm{Mn}$ & $\mathrm{Zn}$ & $\mathrm{Cd}$ & $\mathrm{Cr}$ & $\mathrm{Ni}$ & $\mathrm{Pb}$ \\
\hline $\mathrm{g} \mathrm{kg}^{-1}$ & $\mathrm{mg} \mathrm{kg}^{-1}$ & & $-----n$ & $\mathrm{~mol}_{\mathrm{c}}$ & $\mathrm{kg}^{-1}$ & $-\cdots$ & $\%$ & $-\ldots-1$ & - & 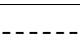 & $-\cdots$ & $\mathrm{mg} \mathrm{kg}$ & $1-\ldots$ & - & (n) & - \\
\hline 24 & 3.0 & 4.2 & 48.5 & 1.2 & 3.0 & 2.0 & 13 & 0.29 & 2.0 & 33.0 & 6.5 & 0.8 & 0.1 & $<0.01$ & $<0.01$ & 0.78 \\
\hline \multicolumn{17}{|c|}{ Granulometric analysis } \\
\hline Clay & \multicolumn{2}{|l|}{ Silt } & \multicolumn{4}{|c|}{ Coarse sand } & \multicolumn{3}{|c|}{ Fine sand } & \multicolumn{4}{|c|}{ Total sand } & \multicolumn{3}{|c|}{ Soil texture } \\
\hline \multicolumn{17}{|c|}{ - } \\
\hline 355 & \multicolumn{2}{|c|}{28} & \multicolumn{4}{|c|}{453} & \multicolumn{3}{|c|}{164} & \multicolumn{4}{|c|}{617} & \multicolumn{3}{|c|}{ Sandy-clayey } \\
\hline
\end{tabular}

'Raij \& Quaggio (1983) and Camargo et al. (1986). 
$\mathrm{NH}_{4} \mathrm{NO}_{3}$ was added at rates of 324, 310, 297, 276, 162 and $0 \mathrm{mg} \mathrm{kg}^{-1}$, for the increasing rates of $\mathrm{Pb}$, respectively $\left(0,100,200,350,1,200\right.$ and $\left.2,400 \mathrm{mg} \mathrm{kg}^{-1}\right)$. After that, soil samples were fertilized with $\mathrm{P}, \mathrm{K}, \mathrm{S}$, $\mathrm{B}, \mathrm{Cu}, \mathrm{Mn}$ and $\mathrm{Zn}$, as follows $\left(\mathrm{mg} \mathrm{kg}^{-1}\right): 360\left(\mathrm{P}^{-} \mathrm{P}_{2} \mathrm{O}_{5}\right)$; $100(\mathrm{~K}-\mathrm{KCl}) ; 30\left(\mathrm{~S}^{\mathrm{o}}\right) ; 0.5\left(\mathrm{~B}-\mathrm{Na}_{2} \mathrm{~B}_{4} \mathrm{O}_{7}\right) ; 1.0(\mathrm{Cu}-$ $\left.\mathrm{CuSO}_{4}\right) ; 8.0\left(\mathrm{Mn}-\mathrm{MnCl}_{2}\right)$ and $2.0\left(\mathrm{Zn}-\mathrm{ZnSO}_{4}\right)$. Phosphate (supertriple - granules) and sulfur (elemental powder) were applied in the solid form and the other elements, in solution. Following, each treated soil sample was split in two parts; and one received disodium-EDTA applied at the rate of $0.5 \mathrm{~g} \mathrm{~kg}^{-1}$ soil (Huang et al., 1997) and the other was not treated.

Maize (cv. IAC-8333) was seeded in $3 \mathrm{dm}^{3}$ plastic pots filled with the treated soil samples (six $\mathrm{Pb}$ rates $\times$ two EDTA rates $\times$ three replications $=36$ pots). Each pot received 24 seeds and after seedling emergence (one week after sowing), six plants per pot were left. The pot soil moisture was daily monitored by pot weighing and adding distilled water whenever necessary to keep $70 \%$ of total soil pores filled with water. Some applications of natural insecticide 'Neem' (Azadirachta indica) were made to control maize leaf caterpillars. Shoots were harvested 45 days after seeding.

\section{Analytical procedures}

Determination of $\mathbf{P b}$ concentrations in plant shoots After harvest, maize shoots were rinsed first in tap water and thereafter in $1 \% \mathrm{HCl}$ solution and distilled water, and dried in a forced-air oven at $70^{\circ} \mathrm{C}$ until constant weight. In sequence the shoot dry matter yields were determined, ground in a Wiley type grinder and submitted to oven digestion (incineration) according to Bataglia et al. (1983).

Oven digestion - One gram of dry and ground plant tissue was oven digested at $500^{\circ} \mathrm{C}$ for 3 hours. After that, ashes were suspended in $5 \mathrm{~mL}$ of a $6 \mathrm{~mol} \mathrm{~L}^{-1}$ $\mathrm{HCl}$ solution and heated on an electrical plate until dry (complete evaporation). The residues were suspended in $\left(2 \mathrm{~mol} \mathrm{~L}^{-1}\right) \mathrm{HCl}$, transferred to $50 \mathrm{~mL}$ volumetric flask and volumes were adjusted with distilled water and filtered through blue-ribbon paper filter (Bataglia et al., 1983). The plant extracts were analysed for $P$, $\mathrm{Ca}, \mathrm{Mg}, \mathrm{Cu}, \mathrm{Fe}, \mathrm{Mn}, \mathrm{Zn}, \mathrm{Al}, \mathrm{Cd}, \mathrm{Cr}, \mathrm{Ni}$ and $\mathrm{Pb}$ by induced coupled plasma emission spectrometry (ICPOES) (Jobin Yvon 40P, Longjumeau, France).

\section{Determination of available $\mathrm{Pb}$ in soil samples}

After soil incubation and before maize seeding, soil samples were thoroughly revolved and $0.2 \mathrm{~kg}$ of soil was collected from every pot. The samples were sieved through a $2 \mathrm{~mm}$-mesh screen and submitted to the following the chemical procedures for the determination of available $\mathrm{Pb}$ :

DTPA - Extracting solution $=0.005 \mathrm{~mol} \mathrm{~L}^{-1}$ diethylenetriaminepentaacetate (DTPA) $+0.1 \mathrm{~mol} \mathrm{~L}^{-1}$ triethanolamine $(\mathrm{TEA})+0.01 \mathrm{~mol} \mathrm{~L}^{-1}$ calcium chloride $\left(\mathrm{CaCl}_{2}\right)$ at $\mathrm{pH}$ 7.3. Procedure according to Lindsay \& Norvel $(1978)-10 \mathrm{~cm}^{3}$ of soil $+20 \mathrm{~mL}$ of extracting solution and 2 hour-shaking. The extracting solution was analyzed for $\mathrm{Pb}$ by ICP-OES.

Mehlich-3 - Extracting solution $=0.2 \mathrm{~mol} \mathrm{~L}^{-1}$ $\mathrm{CH}_{3} \mathrm{COOH}+0.25 \mathrm{~mol} \mathrm{~L}^{-1} \mathrm{NH}_{4} \mathrm{NO}_{3}+0.015 \mathrm{~mol} \mathrm{~L}^{-1}$ $\mathrm{NH}_{4} \mathrm{~F}+0.015 \mathrm{~mol} \mathrm{~L}^{-1} \mathrm{HNO}_{3}+0.001 \mathrm{~mol} \mathrm{~L}^{-1}$ EDTA at $\mathrm{pH}$ 2.5. Procedure described by Mehlich (1984) -5 $\mathrm{cm}^{3}$ of soil $+20 \mathrm{~mL}$ of extracting solution and $5 \mathrm{~min}-$ shaking. The extracting solution was analyzed for $\mathrm{Pb}$ by ICP-OES.

Saturation Extract - Procedure described by Wolt (1994): deionized water was added to $0.5 \mathrm{~kg}$ of soil until the saturation point; the soil paste was then filtered through Buchner funnel with slow-filtering paper-filter, using vacuum, and the extract was collected in an Erlenmeyer flask.

The soil extracts were analyzed for $\mathrm{Pb}$ by ICP-OES. The soil extracts were also analyzed for $\mathrm{Cl}^{-}, \mathrm{NO}_{3}^{-}, \mathrm{NH}_{4}^{+}, \mathrm{SO}_{4}^{2-}, \mathrm{PO}_{4}^{2-}, \mathrm{K}^{+}, \mathrm{Ca}^{2+}, \mathrm{Mg}^{2+}, \mathrm{Zn}^{2+}$, $\mathrm{Cu}^{2+}, \mathrm{Fe}^{3+}, \mathrm{Pb}^{2+}, \mathrm{Al}^{3+}$, electrical conductivity (EC) and $\mathrm{pH}$, as follows: $\mathrm{Cl}^{-}$using a selective electrode $(3 \mathrm{~mL}$ soil solution $+9 \mathrm{~mL}$ buffer at $\mathrm{pH}$ 4.7) (Orion 710-A); $\mathrm{NO}_{3}^{-}$and $\mathrm{NH}_{4}^{+}$, by Kjeldahl method, as described by Cantarella \& Trivelin (2001); $\mathrm{SO}_{4}^{2-}, \mathrm{PO}_{4}^{2-}, \mathrm{Zn}^{2+}, \mathrm{Cu}^{2+}$, $\mathrm{Fe}^{2+}, \mathrm{Pb}^{2+}$ and $\mathrm{Al}^{3+}$ by ICP-OES (respective estequiometric calculations for $\mathrm{P}$ and $\mathrm{S}$ were made); $\mathrm{Ca}^{2+}$ and $\mathrm{Mg}^{2+}$ by atomic absorption spectrometry (Perkin Elmer 5100); $\mathrm{K}^{+}$by flame photometry (Micronal B262); EC using a electrical conductivity meter (Orion C708) and $\mathrm{pH}$ using a $\mathrm{pH}$ meter (Metrohm $692 \mathrm{pH} /$ ionmeter).

All the applied EDTA $\left(0.5 \mathrm{mg} \mathrm{kg}^{-1}\right)$ was considered dissolved in the soil solution. All data obtained was submitted to the geochemistry modeling visualMINTEQ 2.30 (Gustafsson, 2004) to obtain the percent distribution of ionic species in the soil solution.

Results were submitted to analysis of variance and regression with linear or polynomial models $(* P<0.05$ or $* * P<0.001)$ using the software ESTAT v.2.0. (1992).

\section{RESULTS AND DISCUSSION}

\section{Maize phytoextractor potential}

The EDTA chelant applied to the soil caused a decrease in shoot dry matter yield of maize plants (Fig- 
ure 1). Such effect might be explained by the EDTA increase on the availability of heavy metals (HM) or due to EDTA toxicity (Cui et al., 2004).

A previous study using mustard plants grown in nutrient solution containing $0.5 \mathrm{mmol} \mathrm{L}^{-1} \mathrm{de}$ $\mathrm{Pb}\left(\mathrm{NO}_{3}\right)_{2}$ and $2.5 \mathrm{mmol} \mathrm{L}^{-1}$ of EDTA showed that EDTA caused a decrease in leaf tissue water content (Vassil et al., 1998). Similar results were obtained on decreased photosynthesis rate, transpiration and stomata conductance in artichokes (Cynara cardunculus $\mathrm{L}$.) grown in $\mathrm{Pb}$-contaminated soils, with $1.0 \mathrm{mmol} \mathrm{L}^{-1}$ de EDTA (Hernandez-Allica et al., 2003).

In the present study, the decreased maize shoot dry matter yields observed might be attributed to $\mathrm{Fe}$ and $\mathrm{Al}$ concentrations found in shoots (average of $396 \mathrm{mg} \mathrm{kg}^{-1}$ to $405 \mathrm{mg} \mathrm{kg}^{-1}$, respectively). Adequate maize leaf $\mathrm{Fe}$ concentrations usually range from 30 and $250 \mathrm{mg} \mathrm{kg}^{-1}$ (Raij \& Camargo, 1997) and Al concentrations in leaf tissues of most plants range around 50 and $400 \mathrm{mg} \mathrm{kg}^{-1}$ (average of $200 \mathrm{mg} \mathrm{kg}^{-1}$ ) (Bergmann, 1992). The $\mathrm{Fe}$ and $\mathrm{Al}$ values found in maize shoots were above the adequate range and might be attributed to an increase in soil solution metal availability due to the presence of EDTA.

Without EDTA, the Fe and Al concentrations in the soil solution were on average, 0.43 and 1.15 $\mathrm{mg} \mathrm{L}^{-1}$, which are considered below hazard levels. Iron concentrations in the soil solution between 30 and 500 $\mathrm{mg} \mathrm{L}^{-1}$ can cause toxicity in several crops (Sousa et al., 2004) and concentrations of Al higher than 3.6 $\mathrm{mg} \mathrm{L}^{-1}$ usually drastically reduce maize yield (Sparks, 1995). On the other hand, in the presence of EDTA, $\mathrm{Fe}$ and $\mathrm{Al}$ concentrations in the soil solution were fairly high, 107 and $3.6 \mathrm{mg} \mathrm{L}^{-1}$, respectively, being then considered in the range of hazard values.

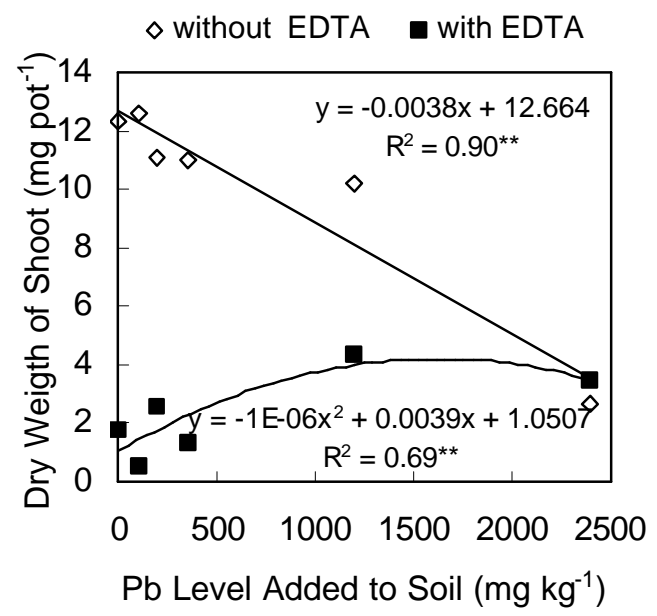

Figure 1 - Effects of increasing $\mathrm{Pb}$ rates and EDTA applied to the soil, on the shoot dry matter yields of 45-day-old maize plants.
Another possibility of the decrease in shoot dry matter is the difference of $\mathrm{P}$ found in shoots. The average over the treatments without EDTA was 15.94 $\mathrm{g} \mathrm{kg}^{-1}$ and with EDTA was $24.6 \mathrm{~g} \mathrm{~kg}^{-1}$.

Maize shoot dry matter $\mathrm{Pb}$ concentrations were not affected by the soil-applied EDTA (Figure 2). The data obtained for shoot $\mathrm{Pb}$ concentrations in relation to the $\mathrm{Pb}$ rates applied to the soil were fit to linear regression equations $\left(R^{2}=0.98\right)$, reaching 1,600 $\mathrm{mg} \mathrm{kg}^{-1}$. Shen et al. (2002); Cui et al. (2004) have reported some expressive increases in shoot $\mathrm{Pb}$ concentrations of several plants in function of EDTA addition to the soil, such as peas, maize, cabbage, Indian mustard and lupines. The latter authors observed a 30fold increase in maize shoot $\mathrm{Pb}$ concentrations (from 100 to $3,000 \mathrm{mg} \mathrm{kg}^{-1}$ ) in the presence of 2,500 $\mathrm{mg} \mathrm{kg}{ }^{-1}$ of total soil $\mathrm{Pb}$ and $0.5 \mathrm{~g} \mathrm{~kg}^{-1}$ of EDTA. A previous study has also shown the influence of five levels (0-2.5 mmol kg-1) of EDTA on maize cultivated on an Ultissol with $500 \mathrm{mg} \mathrm{kg}^{-1}$ of $\mathrm{Pb}$ during eight weeks (Hovsepyan \& Greipsson, 2005). This study showed that EDTA also increases the $\mathrm{Pb}$ shoot concentration and the plants height decrease with the increase of EDTA levels.

The results obtained in the present research might indicate a superior potential for maize cv. IAC8333 as Pb-accumulator. Besides, there is an economical advantage for phytoremediation of contaminated areas with this maize cultivar, since EDTA application is not needed.

There is no good explanation for such high maize shoot $\mathrm{Pb}$ concentrations obtained in treatments without EDTA. One hypothesis might be the maize plant ability to release exudates as organic acids that complex metals (phytosiderophores), favoring their

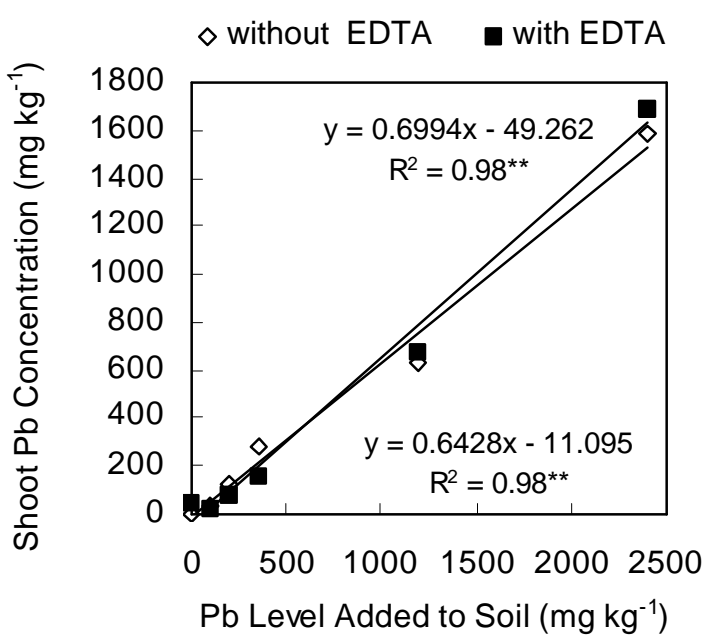

Figure 2 - Relation between $\mathrm{Pb}$ rates applied to the soil and $\mathrm{Pb}$ concentrations in the shoots of 45-day-old maize plants, in the presence and absence of EDTA. 
uptake by roots. There are many evidences of such strategy of metal absorption present in grass roots; von-Wiren et al. (1996) observed Fe and Zn uptake by maize roots bound to organic acids released by the roots in the rizosphere, which are absorbed by specific proteins in the root cell membranes.

Nevertheless, EDTA caused a decrease in dry matter yield and as a consequence, affected the $\mathrm{Pb}$ accumulation in shoots (Figure 3). The relation between $\mathrm{Pb}$ rates applied to the soil and $\mathrm{Pb}$ contents in maize shoots fit quadratic equations, when without EDTA; but fitted linear equations with EDTA application. The maximum shoot $\mathrm{Pb}$ content without EDTA was 7.0 $\mathrm{mg}$ per pot, and with EDTA, $5.7 \mathrm{mg}$ per pot (Figure $3)$.

A plant species potential to remediate a contaminated soil with heavy metals can be assessed using different criteria: by knowing its hyperaccumulation ability and/or calculating the transference factor $(t)$. Depending on the criteria, a plant may or may not be considered a phytoremediator for heavy metals. Hyperaccumulators are those plants able to extract and accumulate in their tissues high metal concentrations, that is, values $>1,000 \mathrm{mg} \mathrm{kg}^{-1} \mathrm{~Pb}$ of dry matter (Raskin et al., 1994). The transference factor $(\boldsymbol{t})$ is defined as the ratio between the total element concentrations in the plant and soil (Henry, 2000). The higher the $t$ factor the more effective the phytoextractor. Based on the former criterion the maize cultivar used in this research can be considered a $\mathrm{Pb}$-hyperaccumulator, since its shoot $\mathrm{Pb}$ concentrations were close to $1,600 \mathrm{mg} \mathrm{kg}^{-1}$ for the highest $\mathrm{Pb}$ rate $\left(2,400 \mathrm{mg} \mathrm{kg}^{-1}\right)$, independently of the presence of EDTA (Figure 2). Based on the latter criterion, the $t$ values calculated for the increasing $\mathrm{Pb}$ rates were the following: $0.36 ; 0.64 ; 0.80 ; 0.52$; and

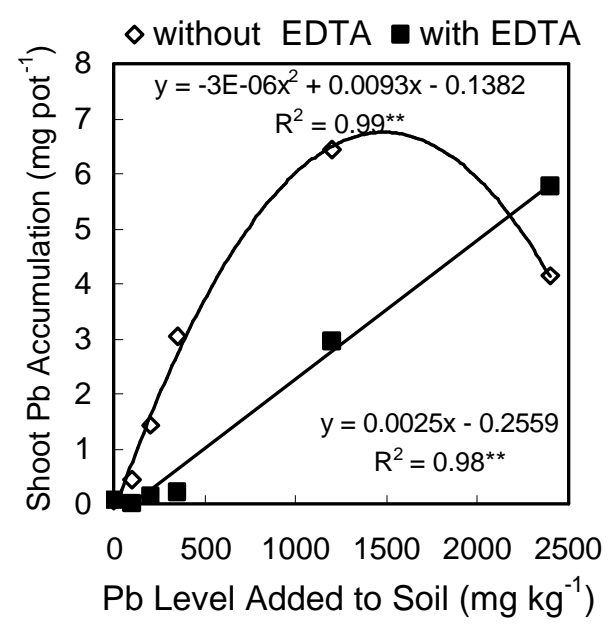

Figure 3 - Relation between $\mathrm{Pb}$ rates applied to the soil and $\mathrm{Pb}$ accumulated in shoots of 45-day-old maize plants, in the presence and absence of EDTA.
0.66 , without EDTA; and 0.24; 0.39; $0.46 ; 0.57$ and 0.70, with EDTA, respectively.

The $t$ values obtained with and without EDTA were very close. However, $t$ values were lower than 1.0 for all treatments. Such values were well below the ones found by Henry (2000) for mustard (Brassica juncea) (1.7), considered an excellent plant for $\mathrm{Pb}$ accumulation. Thus, according to the $t$ criterion, the maize cultivar IAC 8333 is not so effective to remediate $\mathrm{Pb}$-contaminated areas compared to the mustard plants. In spite of that, the cultivar showed to be a good hyperaccumulator in this experiment. Besides, other favorable characteristics such as fast growth, short plant cycle and easy crop management might encourage its recommendation for phytoremediation.

\section{Soil $\mathrm{Pb}$ availability}

In general, the relation between $\mathrm{Pb}$ rates applied to the soil and the $\mathrm{Pb}$ concentrations found in the soil extracts fitted equations, with determination coefficients very similar to each other $\left(\mathrm{R}^{2}=0.99\right)$ for all extracting solutions (DTPA, Mehlich-3 and saturation extract) (Table 2), which means that all solutions were effective to detect the $\mathrm{Pb}$ applied to the soil.

The extracting solution efficacy to assess soil $\mathrm{Pb}$ availability to the plants is usually determined through the relation between the quantities determined in the soil extracts and the quantities accumulated by the plants. With this criterion it was observed that DTPA and Mehlich-3 solutions showed similar effectiveness in assessing the available $\mathrm{Pb}$ to the plants, with $\mathrm{R}^{2}>0.96$ (Figures $4 \mathrm{a}, 4 \mathrm{~b}$ ). These results are in agreement to those obtained by Abreu et al. (2002) studying lettuce (Lactuca sativa L.), signalgrass (Brachiaria decumbens Stapf), elephant grass (Pennisetum purpureum Schumacher), and Brazilian satintail (Imperata brasiliensis). It is also interesting to point out (Figures 4a, 4b) the similarity between the curves obtained with and without EDTA.

The soil solution $\mathrm{Pb}$ analysis (saturation water extract) is another strategy to evaluate soil $\mathrm{Pb}$ availability (Sparks, 1995). The results have shown a polynomial regression relation between $\mathrm{Pb}$ concentrations in the soil solution and $\mathrm{Pb}$ in maize shoots with $\mathrm{R}^{2}=0.90$, for the treatments without EDTA. However, it was not so effective for the treatments with EDTA, with $\mathrm{R}^{2}=0.46$ (Figure 5). For the treatments with EDTA, the saturation extract (soil solution) was the less effective in predicting the soil- $\mathrm{Pb}$ availability as compared to DTPA and Mehlich-3 extracts. These findings are consistent with a previous study that did not show correlation between the soil solution- $\mathrm{Pb}$ and the one found in wheat leaves (Lee et al., 2004). 
Table 2 - Regression analysis between Pb concentrations in the extracts obtained by Mehlich-3, DTPA and saturation extracting solutions methods, and $\mathrm{Pb}$ rates applied to the soil, in the presence or absence of EDTA.

\begin{tabular}{lcc}
\hline Method & Regression Equation & $\mathrm{R}^{2}$ \\
\hline Mehlich-3 & $\mathrm{y}=-0.0001 \mathrm{x}^{2}+1.29 \mathrm{x}-21.94$ & $0.99 * *$ \\
DTPA & $\mathrm{y}=-0.00008 \mathrm{x}^{2}+1.00 \mathrm{x}-16.4$ & $0.99 * *$ \\
Saturation Extract & $\mathrm{y}=0.00006 \mathrm{x}^{2}-0.06 \mathrm{x}+9.10$ & $0.99 * *$ \\
Mehlich-3 & $\mathrm{y}=-0.0001 \mathrm{x}^{2}+1.22 \mathrm{x}-17.41$ & $0.99 * *$ \\
DTPA & $\mathrm{y}=0.84 \mathrm{x}+3.07$ & $0.99 * *$ \\
\hline Saturation Extract & $\mathrm{y}=-0.0003 \mathrm{x}^{2}+0.99 \mathrm{x}+61.90$ & \\
\hline
\end{tabular}

( $\mathrm{y}=\mathrm{Pb}$ concentration, $\mathrm{mg} \mathrm{kg}^{-1}$, in each soil extract type and $\mathrm{x}=\mathrm{Pb}$ rate applied to the soil, $\mathrm{mg} \mathrm{kg}^{-1}$ ).
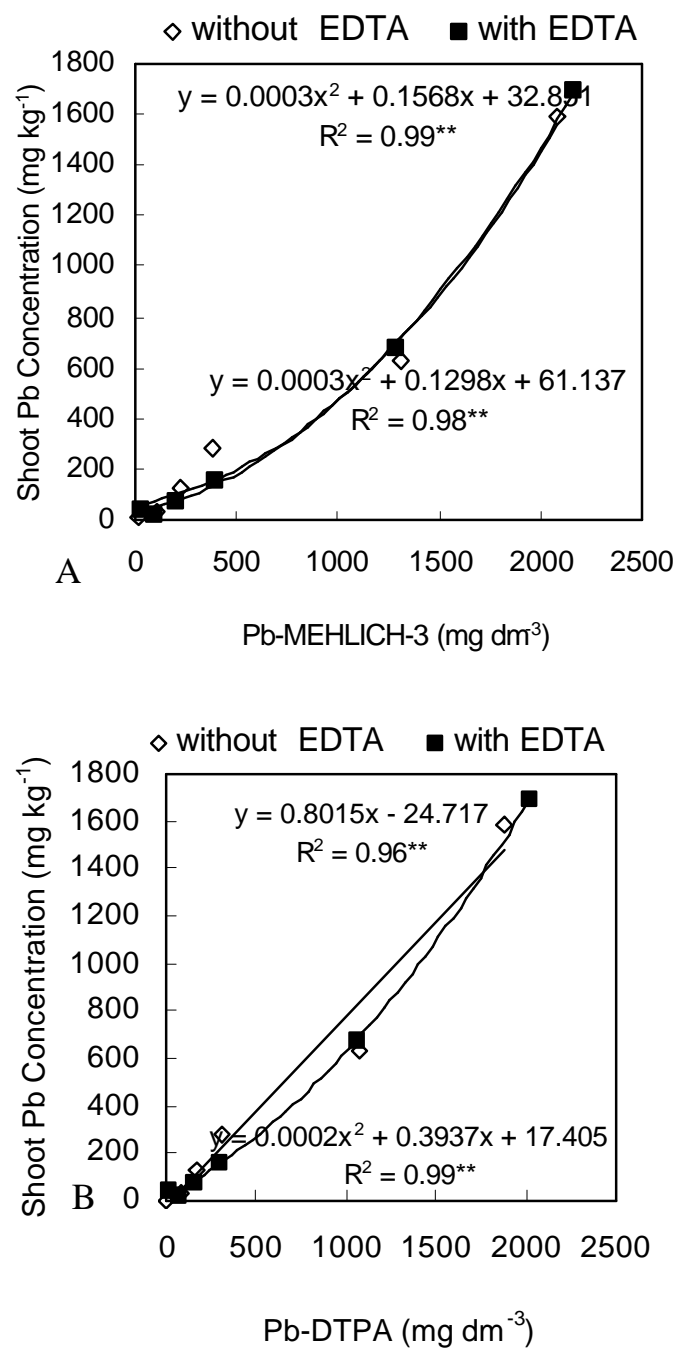

Figure 4 - Relation between $\mathrm{Pb}$ concentrations in the extracts obtained with (a) Mehlich-3 and (b) DTPA extracting solutions and the $\mathrm{Pb}$ concentrations in the shoots of 45-day-old maize plants, in the presence and absence of EDTA.

\section{Ionic speciation in the soil solution}

Chemical analysis of the main ions present in soil solution showed that the total $\mathrm{Pb}, \mathrm{Fe}$ and $\mathrm{Al}$ were

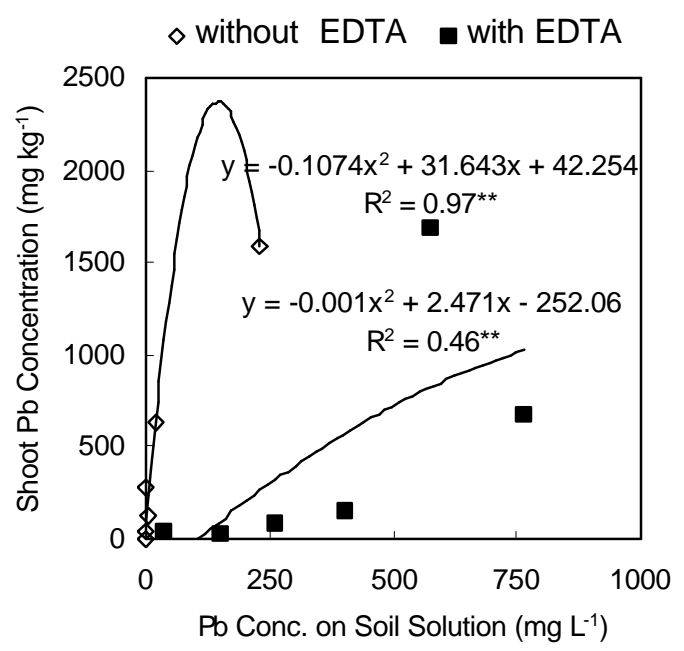

Figure 5 - Relation between $\mathrm{Pb}$ concentration in the soil solution and $\mathrm{Pb}$ concentrations in the shoots of 45-day-old maize plants, in the presence and absence of EDTA.

the most affected elements by $\mathrm{Pb}$ rates and EDTA application to the soil (Figure 6). Soil samples treated with EDTA presented considerable increase in the concentrations of these elements in the soil solution. $\mathrm{Pb}$ concentrations in the soil solution increased up to the rate of $1,200 \mathrm{mg} \mathrm{kg}^{-1}$, decreasing afterwards and the opposite occurred with the $\mathrm{Fe}$ and $\mathrm{Al}$ concentrations (Figure 6). In the soil solution, concentrations of Fe between 30 and $500 \mathrm{mg} \mathrm{L}^{-1}$ may cause toxicity to the several crop species (Sousa et al., 2004) and of Al above $3.6 \mathrm{mg} \mathrm{L}^{-1}$ is known to drastically reduce crop yields, mainly maize (Sparks, 1995). In the present experiment, the $\mathrm{Fe}$ concentrations in the soil solution (Figure 6-b), with EDTA, were within the toxicity levels according to Sousa et al. (2004) for the five $\mathrm{Pb}$ rates. Similar behavior was observed for $\mathrm{Al}$, the concentrations of which in the soil solution were within the toxicity range for the three first $\mathrm{Pb}$ rates (Figure 6-c). Accordingly to the soil solution concentrations, the $\mathrm{Fe}$ and $\mathrm{Al}$ shoot concentrations were also affected. The EDTA treatments showed an average shoot con- 


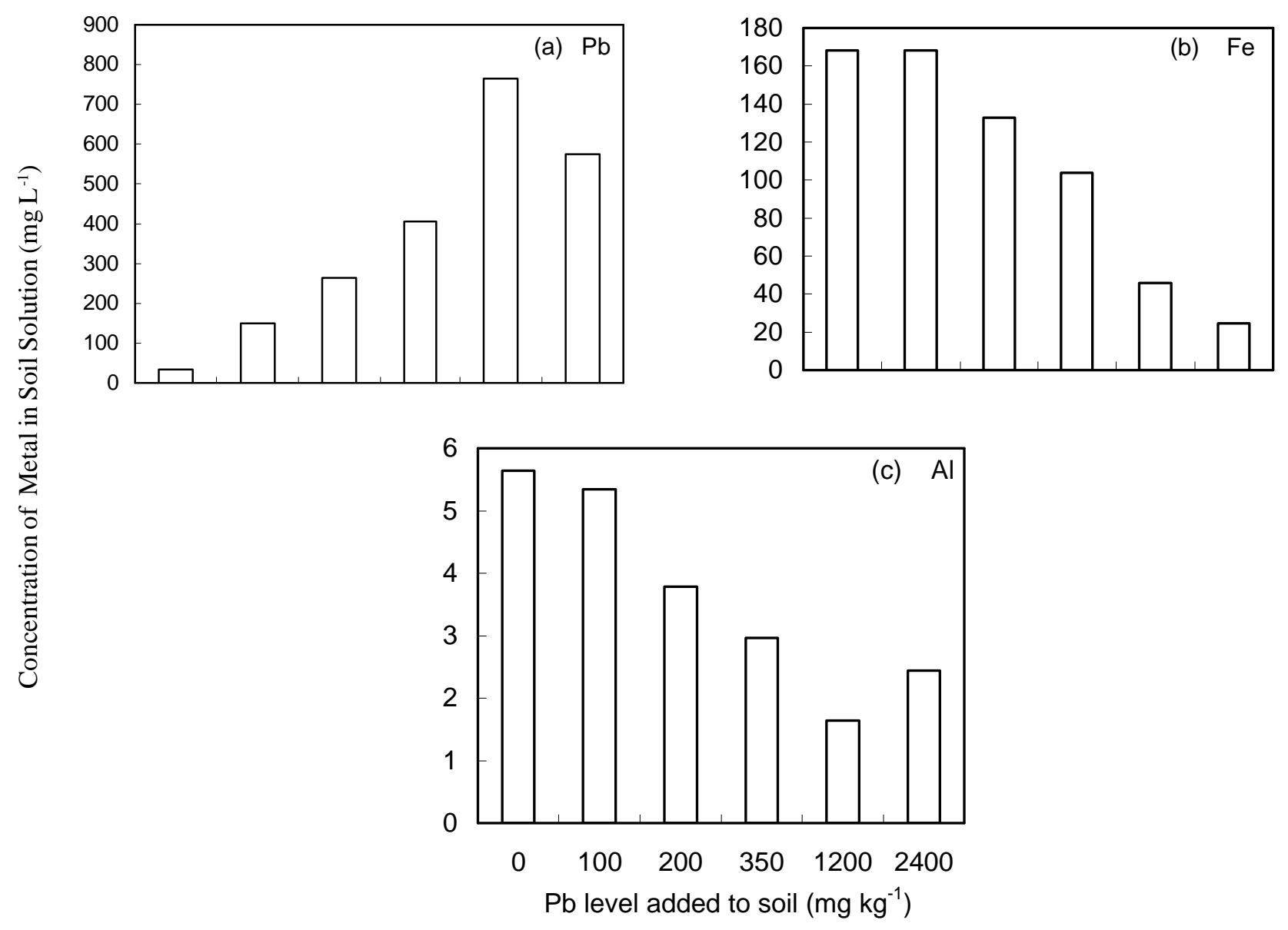

Figure 6 - Effects of $\mathrm{Pb}$ rates and EDTA applied to the soil on the concentrations of (a) $\mathrm{Pb}$; (b) Fe; and (c) Al, in the soil solution.

Table 3 - Percent distribution of main ionic species in the soil solution for different $\mathrm{Pb}$ rates applied to the soil, in the presence and absence of EDTA.

\begin{tabular}{|c|c|c|c|c|c|c|c|}
\hline \multirow{2}{*}{ Ion applied } & \multirow{2}{*}{ Ionic species } & \multicolumn{6}{|c|}{$\mathrm{Pb}$ rates, $\mathrm{mg} \mathrm{kg}^{-1}$} \\
\hline & & 0 & 100 & 200 & 350 & 1,200 & 2,400 \\
\hline & & - & $-\cdots$ & --- & -- & $\cdots$ & $-8-$ \\
\hline & & --- & 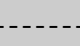 & $---W$ & DTA-. & (n-.... & $-\cdots$ \\
\hline \multirow[t]{3}{*}{$\mathrm{Pb}^{2+}$} & $\mathrm{Pb}^{2+}$ & 71.3 & 66.1 & 68.5 & 67.3 & 74.2 & 77.6 \\
\hline & $\mathrm{PbNO}^{3+}$ & 15.1 & 22.2 & 19.1 & 20.3 & 16.4 & 18.4 \\
\hline & $\mathrm{PbSO}_{4}$ & 10.5 & 8.0 & 9.3 & 9.3 & 6.5 & 2.6 \\
\hline \multirow[t]{3}{*}{$\mathrm{Fe}^{3+}$} & $\mathrm{FeOH}^{2+}$ & 21.0 & 21.4 & 24.9 & 30.0 & 40.2 & 60.7 \\
\hline & $\mathrm{Fe}(\mathrm{OH})^{2+}$ & 76.2 & 78.1 & 73.6 & 69.3 & 58.2 & 34.8 \\
\hline & & 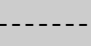 & 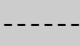 & ----1 & TA--- & $\cdots$ & ------ \\
\hline \multirow[t]{2}{*}{$\mathrm{Pb}^{2+}$} & $\mathrm{PbEDTA}^{2-}$ & 98.6 & 97.9 & 96.7 & 98.3 & 97.4 & 96.3 \\
\hline & PbHEDTA & 1.3 & 2.0 & 3.2 & 1.6 & 2.0 & 3.1 \\
\hline $\mathrm{Fe}^{3+}$ & FeEDTA & 99.8 & 99.8 & 99.7 & 99.8 & 99.7 & 99.7 \\
\hline \multirow[t]{4}{*}{ EDTA $^{4-}$} & PbEDTA $^{2-}$ & 3.0 & 12.3 & 21.2 & 33.2 & 62.1 & 46.5 \\
\hline & AlEDTA- & 3.4 & 3.3 & 2.8 & 1.8 & 1.0 & 1.4 \\
\hline & FeEDTA $^{2-}$ & 52.0 & 51.9 & 41.0 & 32.1 & 14.1 & 7.5 \\
\hline & $\mathrm{CaEDTA}^{2-}$ & 33.3 & 23.2 & 22.0 & 24.7 & 14.0 & 27.7 \\
\hline
\end{tabular}


centration of $396 \mathrm{mg} \mathrm{kg}^{-1}$ of $\mathrm{Fe}$ and $486 \mathrm{mg} \mathrm{kg}^{-1}$ of $\mathrm{Al}$; the treatments without EDTA showed 294 $\mathrm{mg} \mathrm{kg}$ of $\mathrm{Fe} 332 \mathrm{mg} \mathrm{kg}^{-1}$ of $\mathrm{Al}$. Therefore, high $\mathrm{Fe}$ and $\mathrm{Al}$ concentrations in the soil solution were the cause for maize dry matter reduction in treatments with EDTA.

The increase observed in soil solution $\mathrm{Fe}$ and $\mathrm{Al}$ concentrations, inversely related to $\mathrm{Pb}$ rates, is due to the high soil $\mathrm{Fe}$ and $\mathrm{Al}$ contents and their strong affinity with EDTA. Among the metals occurring in the soil, $\mathrm{Fe}^{2+}, \mathrm{Al}^{3+}$ and $\mathrm{Pb}^{2+}$ have higher complex formation constants with EDTA (Baccan et al., 2001). Therefore, the chelant efficacy to bind $\mathrm{Pb}$ decreases as other high affinity elements are present, such as $\mathrm{Fe}^{2+}, \mathrm{Cu}^{2+}, \mathrm{Al}^{3+}, \mathrm{Cd}^{2+}, \mathrm{Zn}^{2+}$ and $\mathrm{Co}^{2+}$, drastically decreasing free $\mathrm{EDTA}^{4-}$ in solution (Geebelen et al., 2002). When $\mathrm{Pb}$ is present in low concentrations, the formation of other metal-EDTA complexes is favored in relation to the $\mathrm{Pb}-\mathrm{EDTA}^{-2}$ complex. Under high $\mathrm{Pb}$ concentrations, the inverse will occur. Therefore, metals compete among each other for EDTA and the one present in higher concentration in the soil solution will prevail for the metal-EDTA ${ }^{4}$ complex formation. This fact is especially relevant for red Oxisols that naturally contain high $\mathrm{Fe}$ and $\mathrm{Al}$ contents.

Without EDTA application, the prevailing form was free $\mathrm{Pb}^{2+}$, which corresponded to $71 \%$ (in average) of the total $\mathrm{Pb}$-forms (Table 3). On the other hand, in treatments with EDTA, most $\mathrm{Pb}$ was bound to EDTA as PbEDTA ${ }^{2-}$ (in average 97\%) and no free $\mathrm{Pb}^{2+}$ was found. Similar behavior was observed for $\mathrm{Fe}$, that is, more than $90 \%$ of total $\mathrm{Fe}$ formed complex with EDTA (FeEDTA'). From the total forms of EDTA $^{4-}$ complex, PbEDTA ${ }^{2-}$ increased from 3.0 to $46.5 \%$, corresponding to the rates of 0 to $2,400 \mathrm{mg}$ $\mathrm{kg}^{-1}$, respectively. The opposite tendency was observed for the complexes AIEDTA; FeEDTA and CaEDTA ${ }^{2-}$, which decreased with the increasing soil $\mathrm{Pb}$ rates. Chelants can desorb heavy metals from the soil matrix and form soluble complexes in the soil solution favoring metal uptake by plant roots (Vassil et al., 1998).

\section{CONCLUSIONS}

The maize cultivar IAC-8333 was effective in accumulating $\mathrm{Pb}$ in the shoots presenting good potential as $\mathrm{Pb}$-phytoextractor. It is not recommended to use EDTA to increase $\mathrm{Pb}$ extraction from Oxisol by maize plants. The extracting solutions Mehlich-3 and DTPA were effective for assessing $\mathrm{Pb}$ availability on soil.

\section{ACKNOWLEDGMENT}

To FAPESP for financial support.

\section{REFERENCES}

ABREU, C.A.; ABREU, M.F.; BERTON, R.S. Análise química de solo para metais pesados. Tópicos em Ciências do Solo, v.2, p.645-628, 2002.

BATAGLIA, O.C.; FURLANI, A.M.C.; TEIXEIRA J.P.F.; FURLANI, P.R.; GALLO, J.R.. 1983. Métodos de análise de plantas. Campinas: Instituto Agronômico, 1983. (Boletim Técnico, 78).

BACCAN, N.; ANDRADE, J.C.; GODINHO, O.E.S.; BARONE, J.S. Titulações complexométricas (In Portuguese). In: BACCAN, N.; ANDRADE, J.C.; GODINHO, O.E.S.; BARONE, J.S. (Ed.). Química analítica quantitativa elementar. Campinas: Edgad Blücher, 2001. p.133-134.

BERGMANN, W. Nutritional disorders of plants: development, visual and analytical diagnosis. New York: G. Fisher, 1992. 741p.

BLAYLOCK, M.J.; SALT, D.E.; DUSHENKOV, S.; ZAKHAROVA, O.; GUSSMAN, C.; KAPULNIK, Y.; ENSLEY, B.D.; RASKIN, I. Enhaced accumulation of $\mathrm{Pb}$ in Indian Mustard by soil-aplied chelationg agents. Environmental Science and Technology, v.31, p.860-865, 1997.

CAMARGO, O.A.; MONIZ, A.C.; JORGE, J.A.; VALADARES, J.M.A.S. Métodos de análise química e física de solos do Instituto Agronômico, Campinas: Instituto Agronômico, 1986.

CANTARELla, H.; TRIVElin, P.C.O. Determinação de nitrogênio inorgânico em solo pelo método da destilação a vapor In: ANDRADE, J.C.; RAIJ, B. van; CANTARELLA, H.; QUAGGIO, J.A. (Ed.). Análise química para avaliação da fertilidade de solos tropicais. Campinas: Instituto Agronômico, 2001. p.270-276.

CHANEY, R.L.; BROWN, S.L.; LI, Y.M.; ANGLE, S.; STUCZYNSKI, T.I.; DANIELS, W.L.; HENRY, C.; SIEBIELEC, G.; MALIK, M.; RYAN, J.A.; COMPTON, H. Progress in risk assessment for soil metals, and in-situ remediation and phytoextraction of metals from hazardous contaminated soils. In: PHYTOREMEDIATION: STATE OF SCIENCE CONFERENCE, Boston, 2000. Washington: USEPA, 2000. p.133.

COMPANHIA DE TECNOLOGIA DE SANEAMENTO AMBIENTAL - CETESB. Relatório de estabelecimento de valores orientadores para solos e águas subterrâneas no Estado de São Paulo. São Paulo, 2001. 245p.

COMPANHIA DE TECNOLOGIA DE SANEAMENTO AMBIENTAL - CETESB. Relação de áreas contaminadas no Estado de São Paulo. São Paulo, 2006.

CUI, Y.; WANG, Q.; DONG, Y.; LI, H.; CHRISTIE, P. Enhanced uptake of soil $\mathrm{Pb}$ and $\mathrm{Zn}$ by Indian mustard and winter wheat following combined soil application of elemental sulphur and EDTA. Plant and Soil, v.261, p.181-188, 2004.

ESTAT 2.0. Sistema de análise de variância estatística. Jaboticabal: Polo Computacional - Departamento de Ciências Exatas - Unesp, 1992.

GEEBELEN, W.; VANGRONSVELD, J.; ADRIANO, D.C.; POUCKE, L.C.V.; CLIJSTERS, H. Effects of Pb-EDTA and EDTA on oxidative stress reactions and mineral uptake in Phaseolus vulgaris. Physiologia Plantarum, v.115, p.377384, 2002.

GUSTAFSSON, J.P. Visual MINTEQ version 2.30. Stockholm: Department of Land and Water Resources Engineering. Exposure Assessment Models. Available at: <http://www.lwr.kth.se/English/ OurSoftware/vminteq/>. Accessed at: 1 oct. 2004.

HERNANDEZ-ALLICA, J.; BARRUTIA, O.; BECERRIL, J.M.; GARBISU, C. EDTA reduces the physiological damage of lead on cardoon plants grown hidroponically. Journal of Physique IV, v.107, p.613, 2003.

HENRY, J.R. An overview of the phytoremediation of lead and mercury. Washington: National Network of Environmental Management Studies - NNEMS, 2000. 51p. 
HOVSEPYAN, A.; GREIPSSON, S. EDTA-enhanced phytoremediation of lead-contaminated soil by corn. Journal of Plant Nutrition. v.28, p.2037-2048, 2005.

HUANG, J.W.; CHEN, J.J.; BERTI, W.R.; Cunningham, S.D. Phytoremediation of lead-contaminated soils: role of synthetic chelates in lead phytoextraction. Environmental Science and Technology, v.31, p.800-805, 1997.

KUMAR, P.B.A.N.; DUSHENKOV, V.; MOTTO, H.; RASKIN, I. Phytoextraction: The use of plants to remove heavy metals from soils. Environmental Science and Technology, v.29, p.1232-1238, 1995.

LEE, T.M.; LAI, H.Y.; CHEN, Z.S.; Effect of chemical amendments on the concentration of cadmium and lead in long-term contaminated soils. Chemosphere, v.57, p.1459-1471, 2004.

LINDSAY, W.L.; NORVELL, W.A. Development of DTPA soil test for zinc, iron, manganese and copper. Soil Science Society of America Journal, v.42, p.421-428, 1978.

MEHLICH, A. Mehlich-3 soil test extractant. A modification of Mehlich-1 extractant. Communications in Soil Science and Plant Analysis, v.15, p.1409-1416,1984.

RAIJ, B. van; CAMARGO, C.E.O. Cereais In: RAIJ, B. van; CANTARELLA, H.; QUAGGIO, J.A.; FURLANI, A.M.C. (Ed.). Recomendações de adubação e calagem para o Estado de São Paulo. Campinas: Instituto Agronômico, 1997. p.45-47. (Boletim Técnico, 100).

RAIJ, B. van; QUAGGIO, J.A. Métodos de análises de solo para fins de fertilidade. Campinas: Instituto Agronômico, 1983. 31p. (Boletim Técnico, 81).

RASKIN, I.; KUMAR, P.N.; DUSHENKOV, S.; SALT, D.E. Bioconcentration of heavy metals by plants. Current Opinions in Biotechnology, v.5, p.285-290, 1994.

ROBINSON, B.; FERNANDEZ, J.E.; MADEJÓN, P.; MARAÑHÓN, T.; MURILLO, J.M.; GREEN, S.; BRENT, C. Phyotoextraction: an assessment of biochochemical and economic viability. Plant and Soil, v.249, p.117-125, 2003.

SHEN, Z.G.; LI, X.D.; WANG, C.C.; CHEN, H.M.; CHUA, H. Lead phytoextraction from contaminated soil with high-biomass plant species. Journal of Environmental Quality, v.31, p.1893-1900, 2002.
SCHMIDT, U. Enhancing phytoextraction: the effect of chemical soil manipulation on mobility, plant accumulation, and leaching of heavy metals. Journal of Environmental Quality, v.32, p.1939-1954, 2003

SOUSA, R.O.; CAMARGO, F.A.O.; VAHL, L.C. Solos alagados; reações de redox. In: MEURER, E.J.. (Org.). Fundamentos de química do solo. 2.ed. Porto Alegre: Gênesis, 2004. p.207237.

SPARKS, D.L. Soil solution-solid phase equilibria. In: SPARKS, D.L., Environmental soil chemisty. 1.ed. London: Academic Press, 1995. p.81-97.

TANDY, S.; BOSSART, K.; MUELLER, R.; RITSCHEL, J.; HAUSER, L.; SCHULIN, R.; NOWACK, B. Extraction of heavy metals from soils using biodegradable chelating agents. Environmental Science and Technology, v.38, p.937-944, 2004.

UNITED STATES ENVIRONMENTAL PROTECTION AGENCY - USEPA. The clean green - phytoremediation. Washington, 2004. Available at: <http://www.clu-in.org/studio/ video.cfm>. Available at: 1 oct 2004.

VASSIL, A.D.; KAPULNIK, Y.; RASKIN, I.; SALT, D.E. The role of EDTA in lead transport and accumulation by Indian mustard. Plant Physiology, v.117, p.447-453, 1998.

von WIREN, N.; MARSCHNER, H.; RÖMHELD, V. Roots of ironefficient maize also absorb phytosiderophore-chelated zinc. Plant Physiology, v.111, p.1119-1125, 1996.

WOLT, J.D. Obtaining soil solution: laboratory methods. In: WOLT, J.D. Soil solution chemistry: applications to environmental science and agriculture. New York: John Wiley \& Sons, 1994. p. $95-120$

Received March 27, 2006

Accepted November 24, 2006 